\title{
IDENTIFIKASI KETERAMPILAN KOGNITIF ANAK USIA 2-6 TAHUN DI LEMBAGA PAUD KECAMATAN SLEMAN, YOGYAKARTA
}

\author{
Nur Hayati, Nur Cholimah, Martha Christianti \\ PAUD FIP Universitas Negeri Yogyakarta
}

e-mail: nurhayati@uny.ac.id; nurcholimah@uny.ac.id; marthachristianti@uny.ac.id

\begin{abstract}
Abstrak
Kemampuan melakukan identifkasi keterampilan kognitif anak usia dini belum dikuasai sepenuhnya oleh guru PAUD. Salah satu kesulitan yang dihadapi guru adalah belum mengetahui jenis instrumen yang dapat mengidentifikasi keterampilan kognitif anak. Selama ini guru hanya menggunakan Standar Tingkat Pencapaian Perkembangan Anak sebagai pedoman melakukan stimulasi terhadap perkembangan kognitif anak usia dini yang diajarnya. Kegiatan pembelajaran akan lebih optimal jika guru melakukan stimulasi berdasarkan kebutuhan dan kemampuan yang dimiliki anak didiknya sesuai hasil identifikasi di awal semester. Penelitian ini bertujuan untuk meningkatkan pengetahuan pendidik anak usia dini tentang identifikasi keterampilan kognitif anak usia dini. Subjek penelitian ini adalah 25 pendidik PAUD di Kecamatan Sleman Kabupaten Sleman. Pengambilan data dilakukan dengan metode observasi yang dilakukan sebelum dan sesudah pelatihan. Hasil penelitian ini menunjukkan bahwa setelah mengikuti pelatihan, subjek mengalami peningkatan pada ketiga materi yang diberikan yaitu identifikasi keterampilan matematika anak usia dini, identifikasi keterampilan sains anak usia dini, dan identifikasi keterampilan bahasa anak usia dini.
\end{abstract}

Kata kunci: keterampilan kognitif, anak usia dini

\section{TRAINING OF IDENTIFYING EARLY CHILDHOOD COGNITIVE SKILL FOR EARLY CHILDHOOD TEACHERS IN SLEMAN REGENCY, YOGYAKARTA}

\begin{abstract}
The ability to identify early childhood cognitive skill has not been fully mastered by the teachers of early childhood education (PAUD). One of the difficulties they faced is that they do not know the instrument which can identify the cognitive skill yet. So far teachers merely use the standard of children's level of achievement in their development (Standar Tingkat Pencapaian Pengembangan Anak) as guideline in stimulating the early childhood cognitive skill of the students. The learning process would be more optimal when the teachers perform stimulation based on the needs and ability possessed by the students which is in line with the prior identification in the beginning of the semester. The research was aimed at improving the teachers' knowledge upon identifying early childhood cognitive skill. The subjects of the study were 25 teachers of early childhood education (PAUD) in Sleman Regency. The data were obtained from the observations carried out before and after the training. The result of the study showed that after joining the training, there were improvements in the three subjects given, namely identifying mathematic skill, identifying science, and identifying language of early childhood students.
\end{abstract}

Keywords: cognitive skill, early childhood students

PENDAHULUAN

Pada masa usia dini, yakni usia 0 sampai 6 tahun pertumbuhan dan perkembangan mengalami peningkatan yang sangat mencolok dan mudah diamati.
Oleh karenanya usia ini merupakan usia yang penting untuk memantau dan memberi stimulasi untuk mengoptimalkan proses pertumbuhan dan perkembangan. Pemantauan yang terarah pada masa ini 
akan membantu optimalisasi pertumbuhan dan perkembangan pada tahap selanjutnya.

Keterampilan yang dimiliki anak pada usia dini sebaiknya distimulasi dengan cara bermain yang menyenangkan. Perkembangan kognitif merupakan salah satu aspek perkembangan yang dimiliki anak usia dini. Namun beberapa fakta menunjukkan bahwa stimulasi keterampilan kognitif anak sebagian besar diberikan dengan cara mengenal angka dan berhitung. Keterampilan kognitif dapat dikenalkan pada anak usia dini dalam berbagai kegiatan antara lain kegiatan pengenalan matematika, sains dan bahasa.

Berdasarkan hasil wawancara dengan 10 pendidik anak usia dini di kantor HIMPAUDI Kecamatan Sleman pada tanggal 14 April 2017, masih banyak orang tua yang menuntut putra putrinya lulus Taman Kanak- kanak mampu membaca, menulis dan berhitung. Hal tersebut tidak bisa disalahkan karena tuntutan agar anak bisa diterima di Sekolah Dasar sebagian besar harus bisa membaca, menulis dan berhitung dengan baik. Dengan demikian, hampir semua pendidik anak usia dini usia TK banyak mengenalkan kemampuan menulis, membaca dan menghitung sejak anak masuk TK. Tindakan tersebut dapat berjalan lebih optimal jika pendidik anak usia dini mampu mengenal dan memahami berbagai komponen keterampilan kognitif yang seharusnya dikenal anak usia 2 sampai 6 tahun.

Komponen keterampilan kognitif yang seharusnya dikenal anak usia dini dalam bidang matematika, sains dan bahasa akan berkembang dengan optimal jika mendapatkan stimulasi yang cepat dan dilakukan dengan cara yang menyenangkan. dengan demikian, semua pendidik anak usia dini harus memahami komponen keterampilan kognitif anak usia dini dari bidang matematika, sains dan bahasa. Hal tersebut diharapkan mampu membekali kemampuan anak dalam menerapkan pengetahuan kognitif dalam kehidupan sehari-hari.

$\begin{array}{cccc}r & \text { Berdasarkan hasil } & \text { wawancara } \\ \text { dengan } 10 & \text { guru } & \text { PAUD di kantor }\end{array}$
HIMPAUDI Kecamatan Sleman, dapat diketahui bahwa salah satu kesulitan guru yaitu belum memiliki instrumen untuk mengidentifikasi keterampilan kognitif anak usia 2-6 tahun. Permasalahan lain yang masih banyak dihadapi guru PAUD adalah belum memiliki banyak pengetahuan yang lebih mendalam untuk mengidentifikasi keterampilan kognitif anak usia dini. Peran yang optimal dengan bekal pengetahuan yang cukup akan membantu tugas pendidik dalam mengantarkan anak didiknya memasuki jenjang pendidikan pada usia selanjutnya. Harapan lebih lanjut adalah anak usia dini dapat bertumbuh dan berkembang secara maksimal sesuai potensi yang dimiliki, tidak hanya pandai matematika tapi juga dapat menjadi pribadi yang mudah bergaul dengan semua orang. Oleh karena itu perlu adanya pelatihan untuk mengoptimalkan kemampuan pendidik dalam mengidentifukasi keterampilan kognitif anak usia dini sesuai dengan kebutuhan anak.

\section{Perkembangan Kognitif Anak Usia Dini}

Salah satu aspek perkembangan yang dikembangkan di Taman Kanakkanak adalah aspek perkembangan kognitif. Perkembangan kognitif berkaitan dengan perkembangan kemampuan berpikir manusia. Seperti yang diungkapkan Gagne (Martini Jamaris, 2006:18) bahwa kognitif adalah proses yang terjadi secara internal dalam pusat susunan saraf manusia yang sedang berpikir.

Tahapan

Perkembangan

Kognitif sesuai dengan teori Piaget menurut Santrock, 1995:167) adalah:

1) Tahap sensorimotor, usia $0-2$ tahun.

Pada masa ini kemampuan anak terbatas pada gerak-gerak refleks, bahas awal, waktu sekarang dan ruang yang dekat saja. 2) Tahap pra-operasional, usia 2 - 7 tahun Masa ini kemampuan menerima rangsangan yang terbatas. Anak mulai berkembang kemampuan bahasanya, walaupun pemikirannya masih statis dan 
belum dapat berpikir abstrak, persepsi waktu dan tempat masih terbatas.

3) Tahap konkret operasional, 7 - 11 tahun Pada tahap ini anak sudah mampu menyelesaikan tugas-tugas menggabungkan, memisahkan, menyusun, menderetkan, melipat dan membagi.

4) Tahap formal operasional, usia $11-15$ tahun

Pada masa ini, anak sudah mampu berfikir tingkat tinggi, mampu berfikir abstrak. Dengan demikian dapat diketahui bahwa anak yang duduk di Taman Kanak-Kanak berada dalam fase praoperasional. Suatu fase perkembangan kognitif yang ditandai dengan berfungsinya kemampuan berpikir secara simbolis. Refleksi dari kemampuan berpikir ini dapat dilihat dari kemampuan anak untuk membayangkan benda-benda yang berada di sekitarnya secara mental. Kemampuan berpikir secara intuitif dan berpusat pada cara pandang anak itu sendiri atau egosentris. Sejalan dengan hal ini, berkembang pula kemampuan konversi yaitu kemampuan untuk memahami perubahan-perubahan yang berkaitan dengan jumlah, ukuran, bentuk, volume dan bidang.

Kemampuan Kognitif Anak Usia 56 Tahun antara lain: (1) Sudah dapat memahami jumlah dan ukuran; (2) Tertarik dengan huruf dan angka. Ada yang sudah mampu menulis dan menyalin serta menghitung; (3) Telah mengenal sebagian besar warna; (4) Mulai mengerti tentang waktu, kapan harus pergi ke sekolah dan pulang dari sekolah, nama-nama hari dalam satu minggu; (5) Mengenal bidang dan bergerak sesuai dengan bidang yang dimilikinya (teritorinya); (6) Pada akhir usia 6 tahun, anak sudah mulai mampu membaca, menulis dan berhitung.(Martini Jamaris, 2006:25).

a. Sains untuk Anak Usia Dini

Pengetahuan sains merupakan pengetahuan tentang ilmu alamiah yang mencakup ilmu fisika, kimia, dan biologi baik pada makhluk hidup maupun makhluk tak hidup. Oleh karena itu dalam mengajarkan sains pada Anak Usia Dini perlu adanya benda kongkret melalui percobaan yang menunjukkan suatu perubahan sehingga dapat memberikan pengalaman yang sangat berharga bagi anak dan pembelajaran yang bermakna.

Ruang lingkup pembelajaran sains adalah mempelajari tentang apa yang ada di alam baik yang terdapat pada mahkluk hidup atau tak hidup. Secara umum Abrucasto (Ali Nugraha, 2012: 93) mengungkapkan bahwa pembelajaran sains meliputi dua dimensi besar, yaitu sains dilihat dari isi bahan kajian dan sains dari bidang pengembangan. Sains dilihat dari isi bahan kajian terdiri dari kajian ilmu bumi dan jagat raya, ilmu hayati (biologi), serta bidang kajian fisika-kimia. Sains dilihat dari bidang pengembangan meliputi penguasaan produk sains, penguasaan proses sains, serta penguasaan sikap sains.

Pengenalan tentang bumi dan jagat raya di Taman Kanak-kanak terintegrasi dengan bidang pengembangan lainnya dalam tema alam semesta. Topik- topik yang biasanya diajarkan meliputi benda langit seperti bulan, bintang, dan matahari, pegunungan, sungai, bencana alam, cuaca serta musim, dan lain sebagainya.

Ilmu hayati atau ilmu biologi meliputi pengenalan mahkluk hidup. Pengenalan ilmu hayati atau biologi di Taman Kanak-kanak biasanya terintegrasi dengan bidang lainnya dalam tema diri sendiri, tumbuhan, dan binatang. Topiktopik yang biasanya diajarkan meliputi pengenalan anggota tubuh, pengenalan tentang panca indera, pengenalan tentang tumbuhan seperti bentuk daun, aroma buah, dan lain sebagainya, serta pengenalan tentang binatang di sekitar anak seperti makanan binatang, jumlah kaki, dan lain sebagainya.

Sains yang terkait dengan fisikakimia meliputi pengenalan sains tentang ilmu fisika dan kimia sederhana. Topiktopik yang biasanya diajarkan seperti tentang gerak benda, konsep terapung dan tenggelam, konsep larut dan tidak larut, dan lain sebagainya. Pengembangan sains meliputi tiga bidang, yaitu penguasaan 
produk sains, penguasaan proses sains, dan penguasaan sikap sains.

Penguasaan produk sains dikatakan Maslichah Asy'ari (2006: 9) sebagai kumpulan pengetahuan yang tersusun dalam bentuk fakta, konsep, prinsip, hukum dan teori. Penguasaan produk sains di Taman Kanak- kanak masih sederhana. Penguasaan produk sains di Taman Kanakkanak terbatas pada fakta, konsep, dan prinsip yang berasal dari kehidupan seharihari anak. Fakta merupakan pernyataan yang benar-benar terjadi. Contohnya bahwa gula rasanya manis. Maslichah Asy' ari (2006: 10) mengungkapkan bahwa konsep adalah abstraksi tentang benda atau peristiwa alam. Contohnya di Taman Kanak-kanak, anak diajarkan konsep bahwa herbivora adalah binatang pemakan tumbuhan. Sedangkan Prinsip dikatakan sebagai generalisasi tentang hubungan antara konsep-konsep yang berkaitan. Contoh produk sains yang berupa prinsip dan dikenalkan di Taman Kanak-kanak adalah es akan mencair bila diletakkan di tempat terbuka atau terkena panas.

Keterampilan proses sains yang dapat dikembangkan di Taman Kanakkanak merupakan keterampilan proses yang sederhana atau keterampilan proses sains dasar (basic science process skills) yang disesuaikan dengan tingkat pencapaian perkembangan. Rezba (Patta Bundu, 2006: 12) menyebutkan keterampilan proses sains dasar meliputi keterampilan mengamati atau mengobservasi, mengklasifikasikan, mengukur, mengkomunikasikan, meramalkan, dan menyimpulkan.

Sikap sains perlu dikembangkan di Taman Kanak-kanak, selain mengembangkan jiwa ilmuwan anak, pengembangan sikap sains juga meningkatkan pemahaman anak terhadap nilai moral, serta mengembangkan aspek kognitif dan sosial emosi anak.

b. Matematika Untuk Anak Usia Dini

Matematika menurut Pamela A. Coughlin (2000:265) merupakan sesuah sistem abstrak untuk pengalaman dalam mengorganisasikan serta mengurutkan.
Penguasaan konsep matematika pada anak usia dini dapat dilakukan melalui permainan dengan benda-benda konkret dan interaksi langsung dengan lingkungan sekitarnya.

Pengenalan matematika bagi anak usia dini menurut Coughlin (2000:265) antara lain berupa korespondensi satu-satu, mengurutkan, berhitung, mengenal penjumlahan dan pengurangan, mengklasifikasikan, pengukuran, perbandingan, mengenal geometri serta mengenal pola.

c. Bahasa Bagi Anak Usia Dini

Perkembangan bahasa pada anak mempunyai bentuk yang berbeda-beda tiap masanya. Papilaya menguraikan tentang kemampuan berbahasa anak sebagai berikut: "Anak usia 5-7 tahun sudah dapat mengartikan kata sederhana, tahu beberapa law.an kata.(Diane E Papilaya, 1982:318). Anak sudah dapat menggunakan beberapa kata sambung, kata depan dan kata sandang dalam pembicaraan sehari-hari. Bahasa egosentrisnya mulai berkembang dan lebih banyak bahasa sosial.

Berdasarkan pernyataan di atas dapat diketahui bahwa anak usia 5-6 tahun masuk ke dalam masa kalimat majemuk dimana kemampuan berbahasa anak mulai meningkat. Anak mampu mengucapkan kalimat yang panjang, dapat menyatakan pendapatnya dengan kalimat majemuk dan mempunyai perbendaharaan kata yang cukup tinggi. Bahasa adalah alat penghubung atau komunikasi antara anggota masyarakat yang terdiri dari individu-individu yang menyatakan pikiran, perasaan, dan keinginannya baik secara verbal maupun melalui simbolsimbol visual (Bromley, 1992). Karakteristik Kemampuan Bahasa Anak Usia 5-6 Tahun: (1) Sudah dapat mengucapkan lebih dari 2.500 kosakata; (2) Lingkup kosakata yang dapat diucapkan anak menyangkut: warna, ukuran, bentuk, rasa, bau, keindahan, kecepatan, suhu, perbedaan, perbandingan, jarak, permukaan (kasar-halus); (3) Anak usia 5-6 tahun sudah dapat melakukan peran sebagai 
pendengar yang baik, (4) Dapat berpartisipasi dalam suatu percakapan. Anak sudah dapat mendengarkan orang lain berbicara dan menanggapi pembicaraan tersebut; (5) Percakapan yang dilakukan oleh anak usia 5-6 tahun telah menyangkut berbagai komentarnya terhadap apa yang dilakukan oleh dirinya sendiri dan orang lain, serta apa yang dilihatnya. Anak pada usia 5-6 tahun sudah dapat melakukan ekspresi diri, menulis, membaca bahkan berpuisi.(Martini Jamaris, 2006:32)

\section{METODE PPM}

Metode PPM ini mengacu pada penelitian survey dengan pendekatan deskriptif kualitatif. Variabel dalam penelitian ini adalah keterampilan guru PAUD mengidentifikasi keterampilan kognitif anak usia dini. Dengan penelitian ini pengabdi dapat mendeskripsikan lebih mendalam keterampilan guru mengidentifikasi keterampilan kognitif anak usia 2-6 tahun di lembaga PAUD sekecamatan Sleman Yogyakarta

Subyek penelitian ini adalah guru PAUD di Kecamatan Sleman Yogyakarta yang berjumlah 25 guru. Lembaga PAUD tersebut antara lain:

Tempat penelitian di 25 lembaga PAUD se-kecamatan Sleman Yogyakarta dan dilaksanakan tanggal 12, 18 dan 19 Agustus 2017. Teknik pengumpulan data penelitian ini menggunakan metode observasi dan dokumentasi. Teknik analisis data yang digunakan adalah analisis data kuantitatif dan kualititatif. Analisis data kuantitatif dilakukan dengan persentase hasil identifikasi keterampilan kognitif. Data kualitatif dilakukan uji kredibilitas data dengan cara triangulasi sumber data.

\section{HASIL DAN PEMBAHASAN Hasil PPM}

Program Pelatihan Identifikasi Keterampilan Kognitif Anak Usia Dini ini dilaksanakan dengan melibatkan pengurus Himpaudi Kecamatan Sleman dan 30 Guru PAUD dari 25 Lembaga PAUD di
Kecamatan Sleman. Kegiatan ini dilaksanakan selama 2 Hari, pada hari pertama diikuti oleh 30 Guru PAUD dan pada hari kedua diikuti 25 Guru PAUD di wilayah Kecamatan Sleman. Kegiatan ini dilakukan dengan ceramah, workshop dan presentasi hasil identifikasi keterampilan kognitif pada anak didik masing-masing.. Kegiatan pelatihan dilaksanakan selama dua hari yaitu hari Sabtu tangg 12 Agustus 2017 dan 19 Agustus 2017. Kegiatan ini terbagi ke dalam 4 (empat) sesi. Adapun deskripsi pelaksanaan kegiatan pelatihan sebagai berikut:

\section{Sesi Pertama}

Pelaksanaan sesi pertama ini dilaksanakan pada tanggal 12 Agustusi 2017 diisi dengan pemaparan materi yang berjudul "Identifikasi Keterampilan Matematika Anak Usia Dini, khususnya usia 2-6 tahun. Materi pertama ini disampaikan oleh Nur Hayati, M.Pd. Perlunya diberikan pengetahuan ini agar guru PAUD lebih memahami secara detail indikator ketarmpilan matematika apa saja yang dapat diidentifikasi pada anak usia dini. Dengan mengetahui gambaran umum tentang keterampilan matematika anak usia dini, diharapkan guru PAUD dapat melakukan kegiatan pembelajaran yang sesuai dengan tahap perkembangan kognitif anak.

\section{Sesi Kedua}

Pelaksanaan sesi kedua ini diisi dengan pemaparan materi yang berjudul "Identifikasi Keterampilan Sains Anak Usia Dini Usia 2 sampai 6 tahun". Pemaparan materi ini disampaikan oleh Nur Cholimah, M.Pd. Perlunya diberikan pengetahuan keterampilan sains anak usia dini ini agar guru PAUD dapat memahami tahap perkembangan sains anak dan dapat mengidentifikasi keterampilan anak melalui berbagai kegiatan selama anak di sekolah. Dengan demikian hasil identifikasi keterampilan sains ini dapat jadikan guru untuk memahami kemampuan anak dan dapat merancang kegiatan pembelajaran 
yang sesuai dengan tahap perkembangan kognitif anak usia dini.

\section{Sesi Ketiga}

Pelaksanaan sesi ketiga diisi dengan pemaparan materi "Identifikasi Keterampilan Bahasa Anak Usia 2-6 Tahun". Materi ini disampaikan oleh Ibu Martha Christianti, M.Pd. Perlunya diberikan materi tersebut adalah agar para guru PAUD memiliki pengetahuan tentang konsep teori bahasa anak usia dini, berbagai indikator keterampilan bahasa anak usia 26 tahun baik dari segi bahasa reseptif, bahasa ekspresif dan bahasa literasi. Pengetahuan ini dapat dijadikan landasan untuk bisa lebih cermat dalam mengidentifikasi keterampilan bahasa anak melalui kegiatan pembelajaran. Dengan pengetahuan awal ini diharapkan para guru PAUD dapat merancang kegiatan pembelajaran sesuai dengan tahapan kemampuan anak usia 2-6 tahun.

\section{Sesi Keempat}

Kegiatan sesi keempat ini diisi dengan diskusi kelompok dan workshop identifikasi keterampilan kognitif yang terdiri dari keterampilan matematika, keterampilan sains dan keterampilan bahasa anak usia 2-6 tahun. Dalam identifikasi keterampilan kognitif, guru dapat mengamati melalui kegiatan pembelajaran. Kegiatan ini dipandu oleh Ibu Nur hayati, M.Pd. Ibu Nur Cholimah, M.Pd dan Ibu Martha Christianti, M.Pd. Kegiatan diskusi tersebut dibagi menjadi 4 kelompok, yaitu 1) kelompok identifikasi usia 2-3 tahun, 2) kelompok identifikasi usia 3-4 tahun, 3) kelompok identifikasi usia 4-5 tahun dan 4) kelompok identifikasi usia 5-6 tahun. Dari hasil diskusi tersebut, guru dapat merancang beberapa indikator untuk mengidentifikasi keterampilan kognitif aak usia dini. Dari 25 guru paud yang hadir dalam pelatihan, 4\% mampu mengidentififikasi keterampilan kognitif anak usia 2 tahun. $32 \%$ guru mampu mengidentifikasi keterampilan kognitif usia 3-3,5 tahun, $40 \%$ peserta mampu mengidentifikasi keterampilan kognitif anak usia 3,6-4 tahun. Data selanjutnya $12 \%$ peserta mampu mengidentifikasi keterampilan kognitif anak usia 4-5 thun dan $12 \%$ mampu mengidentifikasi keterampilan kognitif anak usia 5-6 tahun.

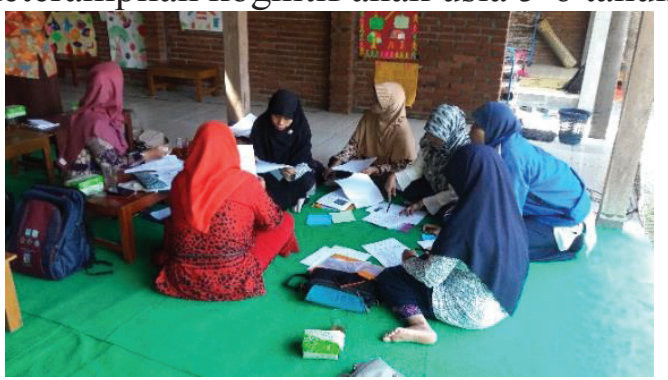

Gambar 1. Kegiatan diskusi merancang identifikasi keterampilan kognitif

\section{Kegiatan Penugasan Identifikasi Keterampilan Kognitif di Sekolah}

Keterampilan kognitif anak dapat diamati di dalam kelas maupun saat anakanak beraktivitas diluar kelas. Adapun keterampilan kognitif yang diidentifikasi antara lain kelompok usia 2-3 tahun, kelompok usia 3-3,5 tahun, kelompok usia 3,5 - 4 tahun, kelompok usia 4 -4,5 tahun, kelompok usia 4,5 - 5 tahun, kelompok usia 5-6 tahun.

Penugasan yang diberikan kepada guru PAUD di sekolah masing masing dilaksanakan pada tanggal 18, 19 dan 25 Agustus 2017. Hasil penugasan dapat diperoleh data bahwa terdapat 1 guru PAUD yang mampu mengidentifikasi keterampilan kognitif anak usia 2 tahun. Guru PAUD yang mampu mengidentifikasi keterampilan kognitif anak usia $3-3,5$ tahun ada 8 orang, guru PAUD yang mampu mengidentifikasi keterampilan kognitif anak usia 3,6 - 4 tahun ada 10 orang. Kemampuan guru PAUD mengidentifikasi keterampilan kognitif anak usia 4-5 tahun ada 3 oarng dan guru PAUD yang mampu mengidentifikasi anak usia 5-6 tahun terdapat 2 orang.

Gambaran kemampuan peserta pelatihan PPM dapat dilihat pada grafik 


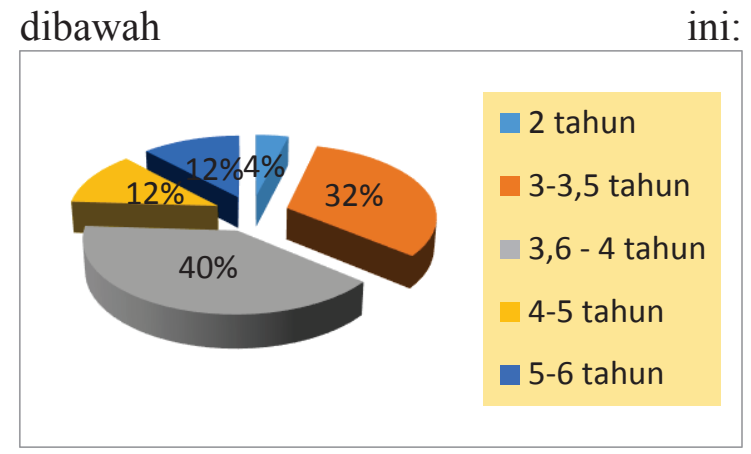

Gambar 2. Grafik kemampuan guru mengidentifikasi keterampilan kognitif anak usia 2-6 tahun

\section{Pembahasan}

Berdasarkan hasil Pelatihan Identifikasi Keterampilan Kognitif Anak Usia 2-6 Tahun pada Guru PAUD di Kecamatan Sleman Yogyakarta, dapat diperoleh hasil evaluasi kegiatan pengabdian masyarakat ini terdiri dari empat indikator, yaitu:
a. kehadiran peserta
b. partisipasi aktif peserta dalam kegiatan diskusi dan workhsop
c. umpan balik peserta terhadap kegiatan pelatihan

d. evaluasi hasil penugasan identifikasi keterampilan kognitif anak usia 2-6 tahun di lembaga PAUD wilayah Kecamatan Sleman.

Berdasarkan indikator pertama kegiatan PPM ini berhasil memenuhi target peserta yaitu sejumlah 25 orang perwakilan guru PAUD diwilayah Kecamatan Sleman. Semua guru PAUD mengikuti kegiatan dari awal sampai dengan akhir dengan antusias, walaupun pada pelaksanaan penugasan terdapat seorang guru yang tidak bisa mengidentifikasi keterampilan kognitif pada anak didiknya karena ada tugas yang lain. Selama kegiatan peserta menunjukkan partisipasi aktif terutama pada sesi workshop dan juga memberikan berbagai umpan balik terhadap kegiatan. Gambar berikut ini memperlihatkan antusiasme peserta dalam mengikuti pemaparan materi yang disampaikan oleh narasumber.

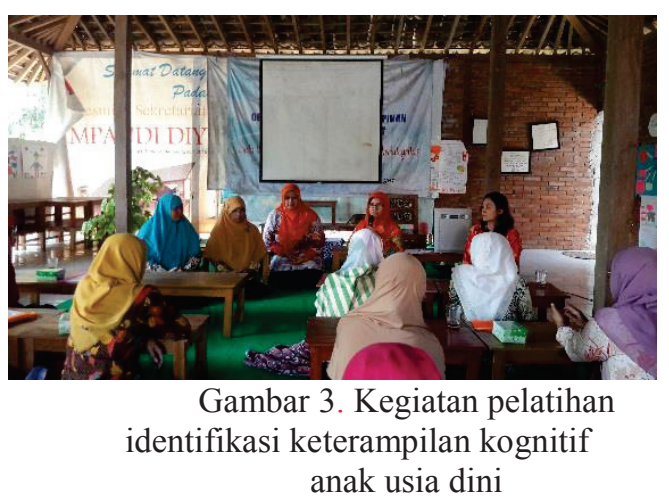

Tim PPM melakukan evaluasi untuk mengetahui tingkat pemahaman guru PAUD dalam mengidentifikasi keterampilan kognitif anak usia dini. Evaluasi dilakukan dengan dua cara yaitu: 1) mengevaluasi hasil identifikasi keterampilan kognitif tiap tahapan usia anak dan 2) wawancara kepada beberapa guru PAUD bagaimana cara mereka mengidentifikasi keterampilan kognitif anak didiknya di sekolah.

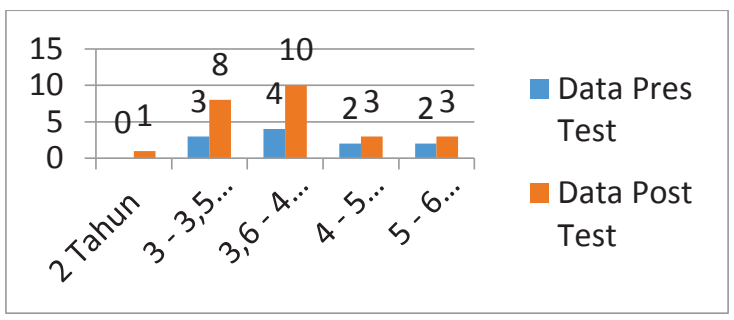

Berdasarkan grafik hasil pretest dan posttest dapat diketahui bahwa keterampilan guru mengalami peningkatan. Guru lebih memahami bagaimana mengidentifikasi keterampilan kognitif anak usia 2-6 tahun sesuai dengan kebutuhan masing masing peserta didiknya.

Evaluasi selanjutnya dilakukan dengan menganalisa keterampilan kognitif yang dicapai anak didik mulai dari usia 2 tahun hingga 6 tahun. Setiap indikator keterampilan kognitif anak didik PAUD usia 2-6 tahun di Kecamatan Sleman memiliki keterampilan kognitif yang berbeda-beda. Kemampuan guru dalam merancang kegiatan pembelajaran untuk dapat mengidentifikasi keterampilan kognitif anak juga berbeda-beda. Ada guru yang kurang kreatif dalam merancang kegiatan pembelajaran dan ada guru yang cukup kreatif merancang kegiatan 
pembelajaran. Sehingga hasil pengamatan identifikasi dapat lebih banyak muncul.

$$
\text { Evaluasi kedua dilakukan }
$$

berdasarkan hasil wawancara dengan guru ketika mengamati keterampilan kognitif anak usia dini. Menurut guru PAUD yang mengamati anak usia 2 tahun, keterampilan sains anak belum semuanya muncul. Hal tersebut dapat dipahami karena keterampilan prosen sains anak usia 2 tahun masih terbatas dalam hal mengamati atau mengobservasi, mengklasifikasikan, mengukur, mengkomunikasikan, meramalkan, dan menyimpulkan (Rezba dalam Patta Bundu, 2006: 12). Keterampilan sains anak usia 2-4 tahun yang banyak muncul baru sampai pada tahap mengobservasi, mengklasifikasi, mengukur dan mengomunikasikan. Sedangkan keterampilan sains dalam meramalkan dan menyimpulkan lebih banyak muncul pada anak usia 4-6 tahun.

Hasil wawancara mengenai keterampilan matematika anak usia 2-6 tahun di 25 lembaga PAUD di Kecamatan Sleman menunjukkan bahwa sebagian besar anak terampil mengurutkan, berhitung, mengklasifikasikan, membandingkan, mengenal geometri serta mengenal pola. Hal tersebut sesuai dengan pendapat Coughlin (2000:265) bahwa keterampilan matematika anak usia dini meliputi korespondensi satu-satu, mengurutkan, berhitung, mengenal penjumlahan dan pengurangan, mengklasifikasikan, pengukuran, perbandingan, mengenal geometri serta mengenal pola.

Hasil wawancara mengenai keterampilan bahasa anak usia 2-6 tahun di 25 lembaga PAUD di Kecamatan Sleman menunjukkan bahwa anak usia 2 tahun mulai terampil menyebutkan nama benda, anak usia 3 tahun mampu menyampaikan keinginannya secara sederhana. Anak usia 4 tahun mampu menjelaskan dengan kata sederhana tentang fungsi benda dan anak usia 5 tahun mampu menulis nama sendiri dan mengenal lawan kata. Hal tersebut sesuai dengan pendapat Diane E Papilaya,
1982:318, bahwa anak usia 5 tahun sudah dapat mengartikan kata sederhana, tahu beberapa lawan kata.

Faktor Pendukung kegiatan Pelatihan Identifikasi Keterampilan Kognitif Anak Usia Dini pada Guru PAUD di Kecamatan Sleman terlaksana berkat kerja sama antar anggota TIM PPM serta adanya kerja sama dengan pengurus Himpaudi kecamatan Sleman. Guru PAUD yang kami undang adalah delegasi dari 25 lembaga PAUD yang ada di wilayah Kecamatan Sleman Yogyakarta. Tempat serta fasilitas kegiatan didukung sepenuhnya oleh pengurus Himpaudi DIY yang bertempat di Padepokan HIMPAUDI DIY di Klegen, Sleman, Yogyakarta. Kegiatan PPM ini dapat terlaksana dengan baik juga berkat kerjasama dengan Jurusan PAUD FIP Universitas Negeri Yogyakarta dalam hal ini diwakili oleh dosen PAUD FIP UNY selaku tim pelaksana kegiatan PPM.

Faktor penghambat kegiatan PPM ini salah satunya dikarenakan jumlah peserta pada saat penugasan berkurang 1 orang karena guru tersebut mendapatkan tugas lain dari lembaganya sehingga tidak mampu membuat dan mengumpulkan tugas.Waktu pelaksanaan workshop merancang identifikasi keteram;ilan kognitif anak usia dini terlalu .singkat, sehingga guru kader terbatas dalam mencari indikator kognitif yang sesuai dengan tahapan anak usia dini. Namun semua guru PAUD yang mengikuti pelatihan dapat mengidentifikasi keterampilan kognitif anak dalam berbagai kegiatan pembelajaran di lembaga PAUD masing-masing.

\section{PENUTUP}

\section{Kesimpulan}

1. Pelatihan ini dapat meningkatkan pemahaman guru PAUD mengenai keterampilan kognitif anak usia dini baik berdasarkan standar tingkat pencapaian perkembangan anak maupun berdasarkan buku kreatif kurikulum. Hal tersebut dapat 
dibuktikan dengan hasil workshop saat pelatihan dan penugasan dapat dikumpulkan dengan baik.

2. Implementasi hasil pelatihan apat diamati secara langsung dari hasil penugasan berupa kegiatan identifikasi keterampilan kognitif anak usia 2-6 tahun di 24 lembaga PAUD wilayah Kecamatan Sleman.

\section{Saran}

1. Perlu adanya sosialisasi kepada guru PAUD mengenai pentingnya pengetahuan mengenai identifikasi keterampilan kognitif anak usia dini dan keterampilan aspek perkembangan lain untuk mengoptimalkan stimulasi perkembangan anak usia dini. Dengan demikian guru dapat lebih cermat melakukan kegiatan stimulasi sesuai dengan kebutuhan anak.

2. Perlu adanya pendampingan lebih lanjut dari TIM UNY khususnya Jurusan PAUD untuk mengimplementasikan programprogram identifikasi dan stimulasi aspek perkembangan anak usia dini agar kemampuan guru PAUD semakin meningkat.

\section{DAFTAR PUSTAKA}

Jamaris, M. (2006). Perkembangan dan Pengembangan Anak Usia Taman Kanak-Kanak Jakarta: Grasindo

Papilaya, D.E. (1982). A Child World Infancy Through Adolescence. New York: Mc Graw Hill

Santrock. (1995). Live Span Development. Jakarta: Airlangga

Tim Direktorat Pembinaan PAUD. (2014). Pedoman Penyusunan Perencanaan Pembelajaran PAUD. Jakarta: Direktorat Jenderal Pendidikan Anak Usia Dini, Nonformal, Dan Informal
Kementerian Pendidikan Dan Kebudayaan RI 